\title{
1. DOWNHOLE VARIATION OF NITROGEN IN HOLE 504B: PRELIMINARY RESULTS ${ }^{1}$
}

\author{
Jörg Erzinger ${ }^{2}$ and Wolfgang Bach ${ }^{2.3}$
}

\begin{abstract}
We report the first data of nitrogen downhole variation in a 2-km-thick section of the ocean crust at DSDP/ODP Site 504. N concentrations in the volcanic section $(275-856 \mathrm{mbsf})$ of Hole $504 \mathrm{~B}$ are $0.73 \pm 0.13 \mathrm{ppm}$, similar to the $\mathrm{N}$ contents of average MORB. The lower sheeted dike complex (SDC) is characterized by significantly lower $\mathrm{N}$ contents of $0.29 \pm 0.17 \mathrm{ppm}$. We interpret this loss of $\mathrm{N}$ as a result of leaching processes at high temperatures. $\mathrm{N}$ data display a similar downhole trend as $\mathrm{Zn}$, which is also depleted in the lower SDC. Therefore the lower SDC may be not only a source for base metals but also for nitrogen. Maximal estimates of the nitrogen flux through hydrothermal leaching, on the basis of the novel $\mathrm{N}$ data presented here, are 1.2 $\times 10^{8} \mathrm{~mol} \mathrm{~N} / \mathrm{yr}$. This is less than $8 \%$ of the estimated present $\mathrm{N}_{2}$ flux at mid-ocean ridges, indicating that hydrothermal leaching plays a minor, though not negligible, role in the geochemical cycle of nitrogen. The effect of addition of $\mathrm{NH}_{4}{ }^{+}$through oxidative alteration of the upper volcanic sequences needs to be evaluated in our ongoing investigations.
\end{abstract}

\section{INTRODUCTION}

The geochemistry of nitrogen in the oceanic crust is still poorly understood. Whereas the majority of nitrogen data are from basaltic glasses and fresh crystalline basalts, the behavior of nitrogen during alteration and nitrogen concentrations of altered rocks are virtually unknown.

The total nitrogen content of a rock is the sum of chemically bound nitrogen (mainly as $\mathrm{NH}_{4}^{+}$) and molecular nitrogen $\left(\mathrm{N}_{2}\right)$, which can be physically dissolved and/or a portion of vesicle gas or fluid inclusions.

Mass spectrometric determinations of $\mathrm{N}$ concentrations in basaltic glasses range from 0.2 to $2.8 \mathrm{ppm}$ (Sakai et al., 1984; Exley et al., 1987; Marty and Lenoble, 1992; Bach and Erzinger, 1995). Marty and Lenoble (1992) suggested that a small amount of $\mathrm{N}(<1 \mathrm{ppm})$ released below $600^{\circ} \mathrm{C}$ could be of organic origin. In the upper extrusive sequences, $\mathrm{NH}_{4}{ }^{+}$is very likely to be enriched in clay minerals formed during oxidative seawater alteration (similar to $\mathrm{K}^{+}$and $\mathrm{Rb}^{+}$). Spilitized basalts of the Cornubian massif in southwest England have ammonium contents up to $200 \mathrm{ppm}$ (Hall, 1989). These basalts, however, rest on continental crust and therefore the addition of ammonium may not solely be a result of rock-seawater interaction.

Both $\mathrm{N}_{2}$ and $\mathrm{NH}_{4}{ }^{+}$are thought to behave as incompatible elements during partial melting and fractional crystallization, with $\mathrm{N}_{2}$ behaving similar to noble gases and $\mathrm{NH}_{4}{ }^{+}$behaving like large ion lithophile elements (e.g., $\mathrm{K}^{+}, \mathrm{Rb}^{+}$).

In basaltic glasses, variable portions $(20 \%-60 \%)$ of $\mathrm{N}$ are trapped as $\mathrm{N}_{2}$ in $\mathrm{CO}_{2}$-rich vesicles, similar to the relative proportion of $\mathrm{He}$ in vesicles (Javoy and Pineau, 1991; Bach and Erzinger, 1995).

One can conclude that numerous secondary processes (alteration, degassing, diffusion) probably have affected the observed $\mathrm{N}$ concentrations in fresh and altered oceanic basalts.

'Alt, J.C., Kinoshita, H., Stokking, L.B., and Michael, P.J., (Eds.), 1996. Proc. ODP, Sci. Results, 148: College Station, TX (Ocean Drilling Program).

${ }^{2}$ GeoForschungsZentrum Potsdam, Projektbereich 4.2, Telegrafenberg, Haus A50, D-14473 Potsdam, Federal Republic of Germany. Erzinger: erz@gfz-potsdam.de; Bach: wbach@gfz-potsdam.de

${ }^{3}$ Present address: Universităt Potsdam. Institut für Geowissenschaften, Postfach 601553, D-14451 Potsdam. Federal Republic of Germany.
DSDP/ODP Hole 504B is the only drill hole in the oceanic crust where we can study the chemical and mineralogical results of hightemperature alteration in situ. Site 504 is located $201 \mathrm{~km}$ south of the modern Costa Rica Rift in 5.9-Ma-old crust. The hole penetrates $274.5 \mathrm{~m}$ of sediment, a $571.5 \mathrm{~m}$ volcanic section, a $209 \mathrm{~m}$ transition zone (TZ), and $1056 \mathrm{~m}$ into a sheeted dike complex (SDC). The upper $310 \mathrm{~m}$ of volcanics were partly altered to Fe-oxyhydroxides, celadonite, saponite, calcite, and zeolites at high seawater/rock ratios and temperatures less than $50^{\circ} \mathrm{C}$. The lower volcanics were partly altered to saponite, pyrite, calcite, zeolites, talc, and mixed-layer smectitechlorite at low water/rock ratios and temperatures less than $150^{\circ} \mathrm{C}$. Greenschist mineral assemblages (chlorite, actinolite, albite, titanite, quartz, and epidote) indicating temperatures up to $380^{\circ} \mathrm{C}$ appear abruptly at 898 meters below seafloor (mbsf) and are present to the bottom of the hole showing increasing temperatures of pervasive background alteration (Alt et al., this volume).

This study has determined nitrogen concentrations of 32 samples from Hole $504 \mathrm{~B}$, using a combined vacuum heating/mass spectrometry method. The samples represent almost the entire drilled crustal section.

\section{SAMPLE PREPARATION AND ANALYTICAL METHODS}

The investigated samples are variably altered rocks drilled during DSDP Legs 69, 70, and 83, as well as ODP Legs 111, 137, and 140. Detailed petrographic descriptions and chemical composition are given in the respective Initial Reports and Scientific Results volumes of the legs (see also the note in Table 1).

The degrees of alteration (i.e., the amount of secondary minerals) in samples from Leg 137 and 140 were visually estimated (cf. Zuleger et al., 1995). Samples were divided into three groups according to the style of alteration. Group D comprises relatively fresh dark diabases, Group $\mathrm{L}$ are light diabases, and Group $\mathrm{P}$ are patches of strong alteration (Table 1; see Alt et al., 1995, for a detailed description).

All samples were crushed and fragments of 1- to 2-mm grain size were selected for vacuum heating. After cleaning the fragments ultrasonically in distilled water, about $500 \mathrm{mg}$ were vacuum-heated at $1300^{\circ} \mathrm{C}$ to release the gaseous content of the samples. Nitrogen concentration was determined by a quadrupole mass spectrometer (QMS) Balzers ${ }^{\mathrm{TM}}$ QMG 112, combined with a gas separation and calibration line. A schematic diagram of the equipment is shown in Fig- 
Table 1. Concentration of nitrogen together with water, carbon dioxide, and zinc data of selected samples from Hole 504B.

\begin{tabular}{|c|c|c|c|c|c|c|c|c|c|}
\hline Leg & Hole & $\begin{array}{l}\text { Core, section, } \\
\text { interval }(\mathrm{cm})\end{array}$ & $\begin{array}{l}\text { Rock } \\
\text { type }\end{array}$ & $\begin{array}{l}\text { Alt. } \\
(\%)\end{array}$ & $\begin{array}{l}\text { Depth } \\
\text { (mbsf) }\end{array}$ & $\stackrel{\mathrm{N}}{\mathrm{N}}$ & $\begin{array}{l}\mathrm{H}_{2} \mathrm{O} \\
\text { (wt\%) }\end{array}$ & $\begin{array}{l}\mathrm{CO}_{2} \\
\text { (wt\%) }\end{array}$ & $\underset{(\mathrm{ppm})}{\mathrm{Zn}}$ \\
\hline 69 & $504 \mathrm{~B}$ & $6 R-2,108-112$ & & & 301.1 & 0.81 & 0.99 & 0.13 & 81 \\
\hline 69 & $504 \mathrm{~B}$ & $9 \mathrm{R}-2,80-83$ & & & 327.8 & 0.46 & 0.83 & 0.08 & 82 \\
\hline 69 & $504 \mathrm{~B}$ & 19R-1. 98-103 & & & 404.0 & 0.83 & 1.20 & 0.10 & 69 \\
\hline 69 & 504B & $27 \mathrm{R}-1,105-110$ & & & 467.1 & 0.73 & 0.63 & 0.09 & 76 \\
\hline 70 & $504 \mathrm{~B}$ & $37 \mathrm{R}-2.94-96$ & & & 555.0 & 0.68 & 0.61 & 0.46 & 57 \\
\hline 70 & $504 \mathrm{~B}$ & $46 R-2,129-131$ & & & 631.8 & 0.83 & 0.46 & 0.09 & 67 \\
\hline 70 & $504 \mathrm{~B}$ & $65 \mathrm{R}-1,20-25$ & & & 782.2 & 0.80 & 0.46 & 0.09 & 63 \\
\hline 83 & $504 \mathrm{~B}$ & $90 R-4,146-149$ & & & 1000.5 & 1.28 & 3.40 & 0.34 & 96 \\
\hline 83 & 504B & $129 \mathrm{R}-2,58-62$ & & & 1272.1 & 1.00 & 1.60 & 0.08 & 81 \\
\hline 111 & 504B & $142 \mathrm{R}-1,14-17$ & & & 1353.0 & 0.69 & 1.08 & 0.05 & 69 \\
\hline iii & $504 \mathrm{~B}$ & $145 \mathrm{R}-3,92-94$ & & & 1382.2 & 0.60 & 1.08 & 0.05 & 57 \\
\hline 111 & $504 \mathrm{~B}$ & $148 \mathrm{R}-1,110-112$ & & & 1407.9 & 0.66 & 0.91 & 0.05 & 76 \\
\hline 111 & $504 \mathrm{~B}$ & I54R-1, 85-87 & & & 1455.2 & 1.29 & 1.24 & 0.04 & 74 \\
\hline 111 & 504B & $|6| R-1,7-9$ & & & 1504.2 & 0.48 & 0.95 & 0.07 & 68 \\
\hline 111 & $504 \mathrm{~B}$ & $163 R-2,1-3$ & & & 1513.1 & 0.85 & 1.48 & 0.03 & 54 \\
\hline 137 & $504 \mathrm{~B}$ & $174 R-2,23-26$ & D & 10 & 1578.0 & 0.14 & 1.21 & 0.06 & 72 \\
\hline 137 & $504 \mathrm{~B}$ & $181 \mathrm{M}-2,95-97$ & P & 25 & 1622.8 & 0.09 & 1.29 & 0.06 & 60 \\
\hline 140 & 504B & $189 \mathrm{R}-2,15-17$ & $\mathrm{P}$ & 85 & 1653.5 & 0.45 & 3.09 & 0.08 & 60 \\
\hline 140 & $504 \mathrm{~B}$ & $190 \mathrm{R}-1,10-14$ & $P$ & 60 & 1655.2 & 0.38 & 5.98 & 0.08 & 61 \\
\hline 140 & $504 \mathrm{~B}$ & $194 R-1,36-40$ & D & 20 & 1680.8 & 0.53 & 1.29 & 0.06 & 67 \\
\hline 140 & $504 \mathrm{~B}$ & $197 \mathrm{R}-1,123-126$ & D & 15 & 1704.0 & 0.40 & 1.71 & 0.09 & 68 \\
\hline 140 & $504 \mathrm{~B}$ & $200 \mathrm{R}-3,115-117$ & D & 15 & 1732.8 & 0.40 & 2.16 & 0.08 & 92 \\
\hline 140 & $504 \mathrm{~B}$ & $203 R-1,15-19$ & L & 45 & 1756.7 & 0.18 & 1.98 & 0.14 & 43 \\
\hline 140 & $504 \mathrm{~B}$ & $207 \mathrm{R}-1,22-26$ & D & 40 & 1768.6 & 0.29 & 1.10 & 0.07 & 50 \\
\hline 140 & $504 \mathrm{~B}$ & $208 R-1,110-114$ & D & 18 & 1779.1 & 0.70 & 1.25 & 0.04 & 56 \\
\hline 140 & $504 \mathrm{~B}$ & $210 \mathrm{R}-1,80-87$ & D & & 1795.7 & 0.12 & 1.29 & 0.06 & 49 \\
\hline 140 & 504B & $214 \mathrm{R}-1,36-40$ & D & 50 & 1819.0 & 0.29 & 1.84 & 0.06 & 39 \\
\hline 140 & $504 \mathrm{~B}$ & $222 \mathrm{R}-1,115-120$ & D & 45 & 1885.8 & 0.17 & 2.42 & 0.07 & 39 \\
\hline 140 & $504 \mathrm{~B}$ & $225 \mathrm{R}-2,29-32$ & D & 15 & 1914.0 & 0.19 & 1.38 & 0.07 & 63 \\
\hline 140 & $504 \mathrm{~B}$ & $227 \mathrm{R}-1,40-46$ & D & & 1924.9 & 0.14 & 1.55 & 0.08 & 44 \\
\hline 140 & 504B & $23 \mid \mathrm{R}-1,0-3$ & L & 60 & 1953.5 & 0.13 & 1.38 & 0.08 & 36 \\
\hline 140 & $504 \mathrm{~B}$ & $238 \mathrm{R}-1,8-9$ & D & 25 & 1992.0 & 0.32 & 1.60 & 0.07 & 40 \\
\hline
\end{tabular}

Notes: $\mathrm{D}=$ dark diabase, $\mathrm{L}=$ light diabase, and $\mathrm{P}=$ alteration patch. Data sources, except for nitrogen, are Hubberten et al. (1983), Emmermann (1985), Zuleger et al. (1995), and unpublished data from our laboratory. Alt.$=$ alteration.

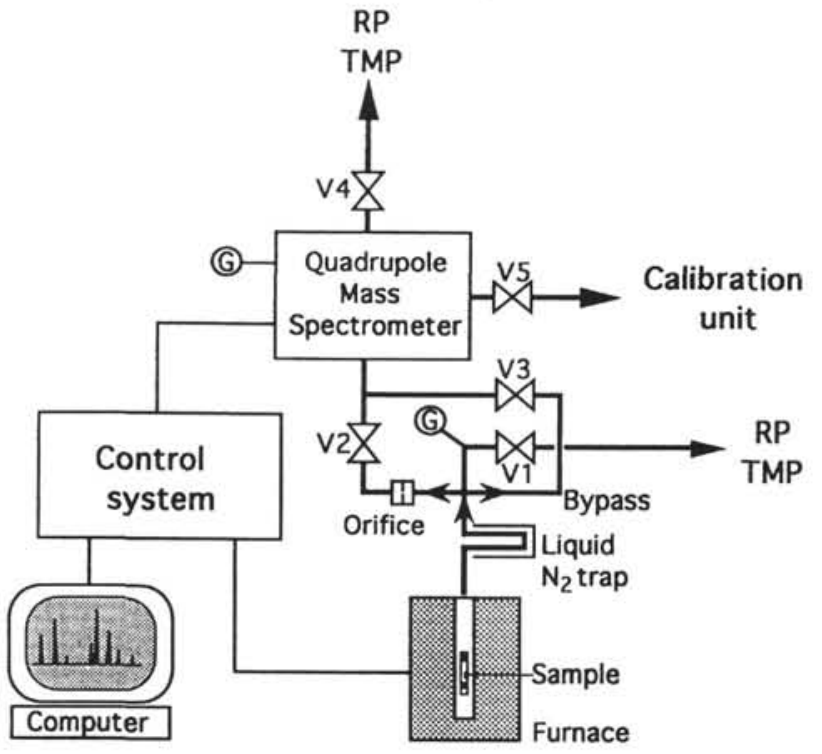

Figure 1. Schematic sketch of the equipment employed for gas analysis. $\mathrm{G}=$ ionization gauges; $\mathrm{V} 1-\mathrm{V} 5=$ valves; $\mathrm{TMP}=$ turbo-molecular pump; and $\mathrm{RP}=$ rotary pump.

ure 1. Total gas contents were determined after heating the sample material in a molybdenum crucible, which was emplaced in an alumina tube. Before analysis, this tube and the crucible were heated to $1400^{\circ} \mathrm{C}$ to decrease the blank values to an acceptable level $(<2 \times$ $10^{-5} \mathrm{~cm}^{3}$ STP, which is below $0.1 \mathrm{ppm} \mathrm{N}$ for a sample of $500 \mathrm{mg}$ ). The samples were baked at $120^{\circ} \mathrm{C}$ in vacuum overnight to remove adsorbed gases and moisture from the fragment surfaces. The furnace then was heated to $1300^{\circ} \mathrm{C}$, with a heating rate of $30^{\circ} \mathrm{C} / \mathrm{min}$. During heating, a cold trap at liquid nitrogen temperature separated $\mathrm{H}_{2} \mathrm{O}$, $\mathrm{CO}_{2}, \mathrm{H}_{2} \mathrm{~S}$, and other condensable gases from the noncondensable gases $\left(\mathrm{N}_{2}, \mathrm{He}, \mathrm{Ar}, \mathrm{H}_{2}, \mathrm{CH}_{4}, \mathrm{CO}\right)$. The noncondensable fraction was led into the mass spectrometer via an orifice after the maximum temperature was maintained for $30 \mathrm{~min}$. After the furnace had cooled, the same procedure was repeated to obtain the blank values, which were subtracted from the sample intensities before the concentrations were calculated. Blank values were always below $0.1 \mathrm{ppm} \mathrm{N}$. The mass spectrometer is calibrated periodically with both pure gases and certified gas mixtures. Mass interferences are corrected using the intensities of subsidiary masses (i.e., $\mathrm{m} / \mathrm{e}=15$ for $\mathrm{CH}_{4}, \mathrm{~m} / \mathrm{e}=12$ for $\mathrm{CO}$, and $\mathrm{m} / \mathrm{e}=14$ for $\mathrm{N}_{2}$ ). Mass interferences with $\mathrm{CO}$ have been a minor problem because the $\mathrm{CO}$ concentrations in the released gas are an order magnitude lower than $\mathrm{N}_{2}$ concentrations. He and Ar concentrations were, at that time, below the detection limits of our method. Four replicates of a basalt laboratory standard yielded $0.30 \pm 0.05$ $(2 \sigma) \mathrm{ppm}$ N.

\section{Discussion of Possible Analytical Problems}

Common mass spectrometric methods cannot distinguish between molecular nitrogen $\left(\mathrm{N}_{2}\right)$ and other $\mathrm{N}\left(\mathrm{NH}_{4}{ }^{+}\right.$, organic $\left.\mathrm{N}\right)$. With our method, we determine $\mathrm{N}$ by analyzing $\mathrm{N}_{2}$ concentration in a gas mixture released upon vacuum heating. The measured $\mathrm{N}_{2}$ may reflect three possible situations. First, all $\mathrm{N}$ is converted to $\mathrm{N}_{2}$ and we measure total $\mathrm{N}$ concentrations. Second, only molecular $\mathrm{N}_{2}$ is released during heating and oxidation of reduced $\mathrm{N}$ did not occur. Third, reduced $\mathrm{N}$ is partly converted to $\mathrm{N}_{2}$.

We think that our $\mathrm{N}$ data represent concentrations of molecular $\mathrm{N}_{2}$ for the following reasons. First, our studies of biotites and muscovites from different locations yielded generally high $\mathrm{NH}_{4}{ }^{+}$concentrations (determined by ion-chromatography following Kjeldahl distillation), whereas the $\mathrm{N}$ concentrations determined by mass spectrometry are an order of magnitude lower (Bach and Erzinger, 1993). This at least proves that a complete conversion of $\mathrm{NH}_{4}{ }^{+}$to $\mathrm{N}_{2}$ does not occur in the 
furnace and gas separation line. Second, all samples from Hole 504B, where mass pyrograms have been monitored, exhibit a unimodal release pattern of $\mathrm{N}_{2}$, which is unlikely if $\mathrm{N}_{2}$ were released by different processes (e.g., degassing of $\mathrm{N}_{2}$ and production of $\mathrm{N}_{2}$ through oxidation of reduced $\mathrm{N}$ ). Some samples show a second peak of $\mathrm{N}_{2}$ at high temperatures around $1450^{\circ} \mathrm{C}$ that could be possibly related to artificially produced $\mathrm{N}_{2}$. Third, our $\mathrm{N}$ data from fresh mid-ocean ridge basalt (MORB) glass (Bach and Erzinger, 1995) indicate that ratios of $\mathrm{N}_{2}$ in vesicles (crushing-released) and total $\mathrm{N}$ released upon heating are similar to the corresponding ratios for $\mathrm{He}$ and $\mathrm{CO}_{2}$, which have similar (or slightly lower) solubilities in basaltic melts. This indicates that the measured total $\mathrm{N}$ cannot be influenced by production of large quantities of $\mathrm{N}_{2}$ through oxidation of $\mathrm{NH}_{4}{ }^{+}$.

We cannot completely rule out that, in some cases, oxidation of reduced $\mathrm{N}$ could have led to slightly elevated $\mathrm{N}_{2}$ values, but, commonly, partial oxidation of $\mathrm{NH}_{4}{ }^{+}$appears to occur only at temperatures above $1400^{\circ} \mathrm{C}$.

Reliable analyses of total $\mathrm{N}$ are extremely difficult to obtain. Previous workers (e.g., Sakai et al. 1984, Exley et al., 1987) oxidized $\mathrm{NH}_{3}$ to $\mathrm{N}_{2}$ in their gas separation lines, but it is very unlikely that the chemically bound $\mathrm{NH}_{4}{ }^{+}$is quantitatively volatilized upon heating. The substantial differences between Instrumental Neutron Activation Analysis (INAA) determination of total $\mathrm{N}$ in fresh basaltic glass (7$10 \mathrm{ppm}$; Norris and Schaeffer, 1982) and mass spectrometric $\mathrm{N}$ determination (0.3-2.8 ppm; e.g., Sakai et al., 1984) could possibly result from the incomplete volatilization of $\mathrm{NH}_{4}{ }^{+}$during pyrohydrolysis. Unfortunately, no international reference rocks or basaltic glasses with certified $\mathrm{N}$ values are available to verify the precision of the applied method.

Our future work will provide data on $\mathrm{NH}_{4}{ }^{+}$concentration and mass spectrometrially measured $\mathrm{N}$ in fresh and altered basalts to better understand the distribution of $\mathrm{N}$ in the oceanic crust and its implications for the nitrogen geochemical circle. $\mathrm{N}$ data presented in this paper are very likely to be concentrations of molecular $\mathrm{N}_{2}$. In the following sections, however, we refer to the measured $\mathrm{N}_{2}$ concentrations as $\mathrm{N}$ contents because we cannot clearly prove the correspondence to the concentration of molecular $\mathrm{N}_{2}$ in the rock.

\section{RESULTS AND DISCUSSION}

The results of the $\mathrm{N}$ determinations are listed in Table 1 together with $\mathrm{H}_{2} \mathrm{O}^{+}, \mathrm{CO}_{2}$, and $\mathrm{Zn}$ values, and, where available, percentage of alteration minerals.

Figure 2 shows the downhole variation of $\mathrm{N}_{1} \mathrm{H}_{2} \mathrm{O}^{+}$, and $\mathrm{Zn}$. As a reference line, the mean $\mathrm{N}$-concentration of oceanic basalt glasses of $0.8 \mathrm{ppm}$ was drawn (Exley et al., 1987; Marty and Lenoble, 1992). The $\mathrm{Zn}$ reference line of $70 \mathrm{ppm}$ was calculated as the average $\mathrm{Zn}$ concentration of the volcanic section of Hole 504B.

The lines in the $\mathrm{H}_{2} \mathrm{O}$ vs. depth plot were calculated as two average values for the volcanic section from 275 to $850 \mathrm{mbsf}$ and for the SDC from 1060 to $2000 \mathrm{mbsf}$, respectively.

The nitrogen content of Hole 504B samples is relatively uniform within the volcanic section from the top of the basement to $800 \mathrm{mbsf}$. The average $\mathrm{N}$ concentrations of the volcanic section are $0.73 \pm 0.13$ $\mathrm{ppm}$. This is close to the $\mathrm{N}$ concentration of average MORB $(0.7$ ppm, Exley et al., 1987; 0.9 ppm, Marty and Lenoble, 1992). Sample 83-504B-90R-4, 146-149 $\mathrm{cm}\left(\mathrm{N}_{2}=1.28 \mathrm{ppm}\right)$ was derived from $1000.5 \mathrm{mbsf}$, the stockwork mineralization zone. Chemically this sample has a higher water content and contains disseminated $\mathrm{Cu}$ and $\mathrm{Zn}$-rich sulfides. In the SDC below $1350 \mathrm{mbsf}, \mathrm{N}$ contents continuously decrease from $0.7 \mathrm{ppm}$ to $0.15 \mathrm{ppm}$. The average $\mathrm{N}$ concentrations of the lowermost part of the SDC (from 1600 to 2000 mbsf) is $0.29 \pm 0.17 \mathrm{ppm}$, indicating a significant loss of $\mathrm{N}$ in the lower SDC. At present we have no explanation for the higher $\mathrm{N}$ content in Samples 83-504B-129R-2, 58-62 cm; 111-504B-154R-1, 85-87 cm; 111-504B-163R-2, 1-3 cm; and 140-504B-208R-1, 110-

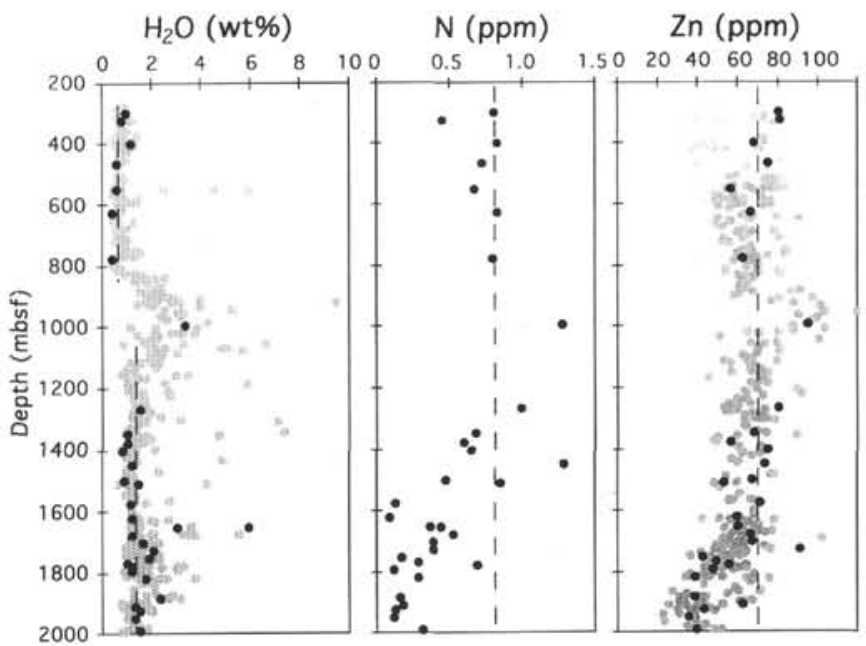

Figure 2. Downhole variations of $\mathrm{H}_{2} \mathrm{O}, \mathrm{N}$, and $\mathrm{Zn}$. Solid dots are from Table 1, stippled dots are data from Autio and Rhodes (1983), Hubberten et al.), Marsh et al. (1983), Emmermann (1985), Kempton et al. (1985), Tual et al. (1985), Autio et al. (1989), Zuleger et al. (1995), and unpublished data from our laboratory. See text for details.

$114 \mathrm{~cm}$. All these samples are mineralogically and chemically similar to the others, except for enrichments in $\mathrm{Cu}$ and occasionally in sulfur. Because no data on $\mathrm{N}$-contents in sulfides are available, and because primary differences in $\mathrm{N}$ contents cannot be ruled out, we cannot determine whether these higher $\mathrm{N}$ contents are of primary or secondary origin.

All investigators (e.g., Hubberten et al., 1983; Emmermann, 1985; Zuleger et al., 1995) have pointed to the remarkable uniformity of both major- and trace-element abundances throughout Hole 504B. Still observed changes in mineralogy and chemistry with depth are generally consistent with increasing temperatures downward, variable water/rock ratios, and degrees of oxidation. Several elements and parameters such as $\mathrm{K}_{2} \mathrm{O}, \mathrm{S}, \mathrm{Tl}, \mathrm{H}_{2} \mathrm{O}, \mathrm{CO}_{2}$, the iron oxidation ratio, and also the abundance of the rare gases $\mathrm{Ar}, \mathrm{Kr}$, and $\mathrm{Xe}$ (Mitchell and Terrell, 1985) show significant changes in concentration at the base of the oxic alteration zone at $585 \mathrm{mbsf}$.Changes in nitrogen concentrations cannot be observed around the oxic/anoxic transition.

Among all major and trace elements determined in the rocks of the sheeted dike section of Hole 504B and published to this date, only $\mathrm{H}_{2} \mathrm{O}, \mathrm{Zn}$, and $\mathrm{N}$ show significant general changes in concentrations downhole (Fig. 2) $\mathrm{H}_{2} \mathrm{O}$ is slightly enriched below the transition zone towards the bottom of the hole resulting from the increasing amount of water-rich secondary alteration minerals at increasing temperatures (Alt and Emmermann, 1985; Zuleger et al., 1995). Zn depletion in the basal SDC is interpreted as a result of hydrothermal leaching processes and may be a source for $\mathrm{Zn}$ in hydrothermal vent fluids and the $\mathrm{Zn}$-enrichment in the mineralized transition zone (Sparks, 1995; Zuleger et al., 1995; Bach et al., this volume).

We therefore interpret the strong depletion of nitrogen downward in the SDC clearly as being the result of a hydrothermal leaching process. Overall, the degrees of alteration, the intensities of fluid-rock interactions, and the background alteration temperatures increase downward in Hole 504B (Alt et al., 1995). The upper volcanic section displays $\mathrm{N}$ concentrations typical of MORB (around $0.7 \mathrm{ppm} \mathrm{N}$ ), which is mainly molecular $\mathrm{N}_{2}$ trapped in vesicles and dissolved in glass. High-temperature hydrothermal alteration of the lower SDC diabases resulted in the breakdown of primary minerals and almost complete alteration of glassy interstitial material. The depletion of $\mathrm{N}$ in the lower SDC rocks therefore indicates that large quantities of the molecular $\mathrm{N}_{2}$ obviously were removed by high-temperature hydrothermal processes. 


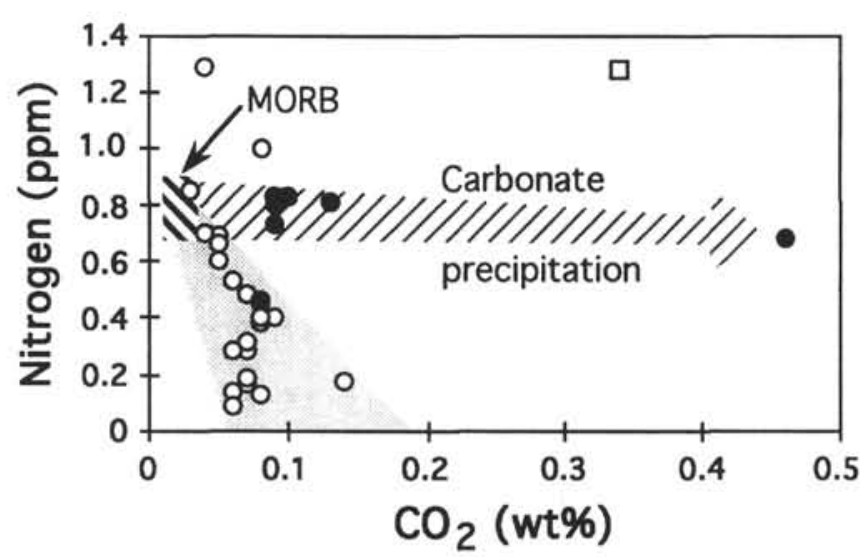

Figure 3. Plot of nitrogen vs. $\mathrm{CO}_{2}$. Open circles indicate rocks from the sheeted dike complex, solid circles are basalts from the volcanic section, and the square represents a sample from the transition zone. The MORB field is drawn from average N data of Marty and Lenoble (1992) and Exley et al. (1987) and from the $\mathrm{CO}_{2}$ data of Fine and Stolper (1986). See text for discussion.

\section{Implications for the Nitrogen Geochemical Cycle}

Degassing of nitrogen from active ridges during emplacement of the magmas occurs via exsolution and segregation of $\mathrm{CO}_{2}$ bubbles (e.g., Javoy and Pineau, 1991). The actual outgassing rate of $\mathrm{N}_{2}$ is, however, difficult to constrain because $\mathrm{N}_{2}$ was rarely determined in vesicle gases. Marty and Lenoble (1992) estimated a maximum $\mathrm{N}_{2}$ flux of $4 \times 10^{9} \mathrm{~mol} / \mathrm{yr}$ based on mean $\mathrm{N} /{ }^{3} \mathrm{He}$ ratios of MORB. Zhang and Zindler (1993) used ${ }^{36} \mathrm{Ar}$ outgassing rates and average $\mathrm{N}_{2} / \mathrm{Ar}$ ratios in vesicles of 54 (Javoy and Pineau, 1991) to estimate a $\mathrm{N}_{2}$ outgassing rate of $3.2(+3.2,-1.6) \times 10^{\circ} \mathrm{mol} / \mathrm{yr}$.

Leaching of nitrogen from the upper oceanic crust during hightemperature alteration reactions is a provable addition to the net flux of $\mathrm{N}_{2}$ at spreading ridges. Nitrogen has been detected in gas samples taken from submarine hydrothermal vents at the Juan de Fuca Ridge (JdFR) and the Valu Fa Ridge in the Lau Basin (VFR). $\mathrm{N}_{2}$ makes up about $12 \%$ of the total amount of dissolved gas (JdFR; Evans et al., 1988 ) and 20\%-40\% (VFR; Fouquet et al., 1993; unpublished data corrected for air-contamination of our laboratory), respectively. In case of the VFR, only $10 \%-30 \%$ of the nitrogen in vent fluids possibly originated from $\mathrm{N}_{2}$ dissolved in the downwelling seawater (calculations are based on the seawater $\mathrm{N}$ concentration of Craig et al., 1967). However, the majority of $N_{2}$ is clearly leached from the basement rocks.

Whereas the degassing of MORB magmas is strictly controlled by melt-vapor partitioning of volatiles, the hydrothermal leaching is not. It is interesting that the depleted mantle is variably degassed in respect to different volatiles. For instance, the depletion of ${ }^{36} \mathrm{Ar}$ is $99.7 \%,{ }^{3} \mathrm{He} 97 \%$, the depletion of $\mathrm{N}$ is $88 \%$, and that of $\mathrm{CO}_{2}$ is only 28\% (Zhang and Zindler, 1993, and references therein). These discrepancies contrast the similar solubilities of $\mathrm{N}_{2}$ and $\mathrm{Ar}$ on the one hand and $\mathrm{He}$ and $\mathrm{CO}_{2}$ on the other hand (e.g., Jambon and Zimmermann, 1987). This can be interpreted as indicating recycling of $\mathrm{C}$ and $\mathrm{N}$ by means of subduction (e.g., $\mathrm{CO}_{2}$ as carbonate and organic $\mathrm{C}$ in sediments, and $\mathrm{N}$ as an organic component in sediments). The compiled values indicated that $\mathrm{C}$ must have been preferentially recycled as compared to $\mathrm{N}$. This was explained by recycling of carbonate sediments through subduction or partitioning of $\mathrm{N}$ in the Earth's core (Marty and Lenoble, 1992).

Hydrothermal alteration could also contribute to a preferential recycling of $\mathrm{C}$, if the basaltic oceanic crust acts as a sink for $\mathrm{C}$ but a source for $\mathrm{N}$. Figure 3 depicts the measured $\mathrm{N}$ concentration plotted against $\mathrm{CO}_{2}$ concentrations. It becomes obvious that $\mathrm{CO}_{2}$ concentrations of all Hole 504B rocks are higher than MORB (maximum of $360 \mathrm{ppm}$ dissolved $\mathrm{CO}_{2}$; Fine and Stolper, 1986) but N concentrations are lower in most rocks from the SDC. This indicates a net loss of $\mathrm{N}$ from the oceanic crust through hydrothermal alteration. In contrast, $\mathrm{CO}_{2}$ concentrations in Hole 504B are much higher than in fresh MORB glasses. Carbonate precipitation in the upper part of the crust adds $\mathrm{CO}_{2}$ to the rock but apparently does not change the $\mathrm{N}$ contents. Oxidative seawater alteration is, however, likely to add nitrogen through enrichments of $\mathrm{NH}_{4}{ }^{+}$. If $\mathrm{NH}_{4}{ }^{+}$behaves indeed like large alkali ions, it would be enriched in the upper oxic volcanic section but leached during nonoxidative high-temperature hydrothermal alteration. In short, overall enrichment of $\mathrm{CO}_{2}$ in the altered crust and drastic depletion of nitrogen in the lower SDC might be a possible additional effect for the preferential recycling of carbon into the mantle. We need more information on ammonium contents in Hole 504B to quantify this model.

Simple mass-balance calculations can prove the importance of hydrothermal leaching for the outgassing rates of $\mathrm{N}$ at mid-ocean ridges. The total volume of the oceanic crust is about $2 \times 10^{9} \mathrm{~km}^{3}$ (Kay and Hubbard, 1978). If the average $\mathrm{N}_{2}$ concentration of MORB is 0.8 $\mathrm{ppm}\left(2.9 \times 10^{-8} \mathrm{~mol} / \mathrm{g}\right)$, the oceanic crust would contain $1.7 \times 10^{17}$ mol $\mathrm{N}_{2}$ (assuming an average density of $3 \mathrm{~g} / \mathrm{cm}^{3}$ ). This is low as compared to the content of the atmosphere $\left(1.38 \times 10^{20} \mathrm{~mol} \mathrm{~N}_{2}\right.$; Ozima and Podosek, 1983) and the continental crust $\left(4 \times 10^{19} \mathrm{~mol} \mathrm{~N}_{2}\right.$; Wlotzka, 1972). Assuming the yearly production rate of basalts at mid-ocean ridges is $3.3-4.3 \times 10^{16} \mathrm{~g}$ (Kay and Hubbard, 1978) the amount of $\mathrm{N}$ transferred from the mantle to the ocean crust would be $0.9-1.2 \times 10^{9}$ mol $\mathrm{N}_{2} / \mathrm{yr}$. This is less than the lower limit for the estimated outgassing rate of $\mathrm{N}$ (about $1.6 \times 10^{9} \mathrm{~mol} / \mathrm{yr}$; Zhang and Zindler 1993), indicating that a substantial fraction of the $\mathrm{N}_{2}$ degasses upon magma ascent and eruption. If we assume that hydrothermal leaching, on average, removes $0.5 \mathrm{ppm}$ molecular $\mathrm{N}_{2}$ from a SDC of $1 \mathrm{~km}$ thickness, the yearly degassing rate would be $0.94-1.25 \times 10^{8} \mathrm{~mol} \mathrm{~N}_{2} / \mathrm{yr}$ (assuming the average crustal thickness is $6 \mathrm{~km}$ ). This makes up at most $8 \%$ of the present outgassing rate of $\mathrm{N}_{2}$.

\section{CONCLUSIONS}

From the results of this preliminary study we conclude that molecular nitrogen, which is originally dissolved in the basaltic matrix or a constituent of vesicle filling, is being leached or degassed from the deeper oceanic crust as a result of increasing temperatures with depth.

Hydrothermal leaching of $\mathrm{N}$ is a potential additional source for the nitrogen flux from the mantle. It is, however, not efficiently changing net nitrogen fluxes and therefore plays a minor role in the nitrogen geochemical cycle.

The question whether the effects of hydrothermal alteration can contribute to the preferential recycling of $\mathrm{C}$ as compared to $\mathrm{N}$ cannot be answered yet. The analytical technique used here cannot determine total nitrogen contents or clearly distinguish between $\mathrm{N}_{2}$ and $\mathrm{NH}_{4}{ }^{+}$; thus, a possible enrichment of total nitrogen in the upper oxic volcanic section was not detectable. Continuation of this work, including determination of $\mathrm{NH}_{4}^{+}$and nitrogen isotopes, is planned.

\section{ACKNOWLEDGMENTS}

This work was supported by the Deutsche Forschungsgemeinschaft (Bonn-Bad Godesberg), Grant No. Er 123/4-2. We thank an anonymous referee for a careful and critical review. 


\section{REFERENCES}

Alt, J.C., and Emmermann, R., 1985. Geochemistry of hydrothermally altered basalts: Deep Sea Drilling Project Hole 504B. In Anderson, R.N., Honnorez, J., Becker, K., et al., Init. Repts. DSDP, 83: Washington (U.S. Govt. Printing Office), 249-262.

Alt, J.C., Zuleger, E., and Erzinger, J.A., 1995. Mineralogy and stable isotopic compositions of the hydrothermally altered lower sheeted dike complex, Hole 504B, Leg 140. In Erzinger, J., Becker, K., Dick, H.J.B., and Stokking, L.B. (Eds.), Proc. ODP, Sci. Results, 137/140: College Station, TX (Ocean Drilling Program), 155-166.

Autio, L.K., and Rhodes, J.M., 1983. Costa Rica Rift Zone basalts: geochemical and experimental data from a possible example of multistage melting. In Cann, J.R., Langseth, M.G., Honnorez, J., Von Herzen, R.P., White, S.M., et al., Init. Repts. DSDP, 69: Washington (U.S. Govt. Printing Office), 729-745.

Autio, L.K., Sparks, J.W., and Rhodes, J.M., 1989. Geochemistry of Leg 11 I basalts: intrusive feeders for highly depleted pillows and flows. In Becker, K., Sakai, H., et al., Proc. ODP, Sci. Results, 111: College Station, TX (Ocean Drilling Program), 3-16.

Bach, W., and Erzinger, J., 1993. Geochemistry of volatile components in rocks from the KTB-HB. In Emmermann, R., Lauterjung, J., and Umsonst, T. (Eds.), NLfB, KTB-Report 93-2: Stuttgart (SchweizerbartVerlag), 465-468.

1995. Volatile components in basalts and basaltic glasses from the EPR at $9^{\circ} 30^{\prime}$ N. In Batiza, R., Storms, M.A., and Allan, J.F. (Eds.), Proc. ODP, Sci. Results, 142: College Station, TX (Ocean Drilling Program), 23-29.

Craig, H., Weiss, R.F., and Clarke, W.B., 1967. Dissolved gases in the equatorial and south Pacific Ocean. J. Geophys. Res., 72:6165-6181.

Emmermann, R., 1985. Basement geochemistry, Hole 504B. In Anderson, R.N., Honnorez, J., Becker, K., et al., Init. Repts. DSDP. 83: Washington (U.S. Govt. Printing Office), 183-199.

Evans, W.C., White, L.D., and Rapp, J.B., 1988. Geochemistry of some gases in hydrothermal fluids from the southern Juan de Fuca Ridge. $J$. Geophys. Res., 93:609-616.

Exley, R.A., Boyd, S.R., Mattey, D.P., and Pillinger, C.T., 1987. Nitrogen isotope geochemistry of basaltic glasses: implications for mantle degassing and structure? Earth Planet. Sci. Lett., 81:163-174.

Fine, G., and Stolper, E., 1986. Dissolved carbon dioxide in basaltic glasses: concentrations and speciation. Earth Planet. Sci. Lett., 76:263-278.

Fouquet, Y., von Stackelberg, U., Charlou, J.L., Erzinger, J., Herzig, P.M., Mühe, R., and Wiedicke, M., 1993. Metallogenesis in back-arc environments: the Lau Basin example. Econ. Geol., 88:2154-2181.

Hall, A., 1989. Ammonium in spilitized basalts of southwest England and its implications for the recycling of nitrogen. Geochem. J., 23:19-23.

Hubberten, H.-W., Emmermann, R., and Puchelt. H., 1983. Geochemistry of basalts from Costa Rica Rift Sites 504 and 505 (Deep Sea Drilling Project Legs 69 and 70). In Cann, J.R., Langseth, M.G., Honnorez, J., Von Herzen, R.P., White, S.M., et al., Init. Repts. DSDP, 69: Washington (U.S. Govt. Printing Office), 791-803.

Jambon, A., and Zimmermann, J.L., 1987. Major volatiles from a North Atlantic MORB glass and calibration to He: a size fraction analysis. Chem. Geol., 62:177-189.
Javoy, M., and Pineau, F., 1991. The volatiles record of a "popping" rock from the Mid-Atlantic Ridge at $14^{\circ} \mathrm{N}$ : chemical and isotopic composition of gas trapped in the vesicles. Earth Planet. Sci. Lett., 107:598-611.

Kay, R.W., and Hubbard, N.J., 1978. Trace elements in ocean ridge basalts. Earth Planet. Sci. Lett, 38:95-116.

Kempton, P.D., Autio, L.K., Rhodes, J.M., Holdaway, M.J., Dungan, M.A., and Johnson, P., 1985. Petrology of basalts from Hole 504B, Deep Sea Drilling Project, Leg 83. In Anderson, R.N., Honnorez, J., Becker, K., et al., Init. Repts. DSDP, 83: Washington (U.S. Govt. Printing Office), 129164.

Marsh, N.G., Tarney, J., and Hendry, G.L., 1983. Trace-element geochemistry of basalts from Hole 504B, Panama Basin, Deep Sea Drilling Project Legs 69 and 70. In Cann, J.R., Langseth, M.G., Honnorez, J., Von Herzen, R.P., White, S.M., et al., Init. Repts. DSDP, 69: Washington (U.S. Govt. Printing Office), 747-763.

Marty, B., and Lenoble, M., 1992. Nitrogen in MORB: a CO 2 , He, Ar study. Eos, 73(Suppl.):349. (Abstract)

Mitchell, J.G., and Terrell, D.J., 1985. Downhole variation of potassium. inert gas abundance, and apparent K-Ar age in basalts from the Costa Rica Rift, Hole 504B, Leg 83, Deep Sea Drilling Project. In Anderson, R.N., Honnorez, J., Becker, K., et al., Init. Repts. DSDP, 83: Washington (U.S. Govt. Printing Office), 305-312.

Norris, T.L., and Schaeffer, O.A., 1982. Total nitrogen content of deep sea basalts. Geochim. Cosmochim. Acta, 46:371-379.

Ozima, M., and Podosek, F.A., 1983. Noble Gas Geochemistry: Cambridge (Cambridge Univ. Press).

Sakai, H., Des Marais, D.J., Ueda, A., and Moore, J.G., 1984. Concentrations and isotope ratios of carbon, nitrogen and sulfur in ocean-floor basalts. Geochim. Cosmochim. Acta, 48:2433-2441.

Sparks, J.W., 1995. Geochemistry of the lower sheeted dike complex, Hole 504B, Leg 140. In Erzinger, J., Becker, K., Dick, H.J.B., and Stokking, L.B. (Eds.), Proc. ODP, Sci. Results, 137/140: College Station, TX (Ocean Drilling Program), 81-98.

Tual, E., Jahn, B.M., Bougault, H., and Joron, J.L., 1985. Geochemistry of basalts from Hole 504B, Leg 83, Costa Rica Rift. In Anderson, R.N., Honnorez, J., Becker, K., et al., Init. Repts. DSDP, 83: Washington (U.S. Govt. Printing Office), 201-214.

Wlotzka, F., 1972. Nitrogen. In Wedepohl, K.-H. (Ed.), Handbook of Geochemistry (Vol. 2/1): Berlin (Springer-Verlag).

Zhang, Y., and Zindler, A., 1993. Distribution and evolution of carbon and nitrogen in Earth. Earth Planet. Sci. Lett., 117:331-345.

Zuleger, E., Alt, J.C., and Erzinger, J.A., 1995. Primary and secondary variations in major and trace-element geochemistry of the lower sheeted dike complex: Hole 504B, Leg 140. In Erzinger, J., Becker, K., Dick, H.J.B., and Stokking, L.B. (Eds.), Proc. ODP, Sci. Results, 137/140: College Station, TX (Ocean Drilling Program), 65-80.

Date of initial receipt: 23 August 1994

Date of acceptance: 14 March 1995

Ms 148SR-156 